\title{
Mercury concentration in different tissues of Podocnemis unifilis (Troschel, 1848) (Podocnemididae: Testudines) from the lower Xingu River - Amazonian, Brazil
}

\author{
Souza-Araujo, J. ${ }^{a *}$, Giarrizzo, T. ${ }^{a}$ and Lima, MO. ${ }^{b}$ \\ ${ }^{\mathrm{a}}$ Grupo de Ecologia Aquática, Universidade Federal do Pará - UFPA, Av. Perimetral, 2651, Terra Firme, \\ CEP 66040-170, Belém, PA, Brazil

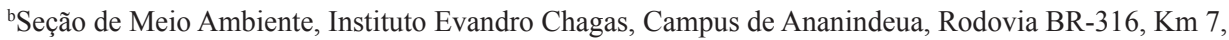 \\ s/n, Levilândia, CEP 67030-000, Ananindeua, PA, Brazil \\ *e-mail: j.araujo.bio@gmail.com
}

Received: May 12, 2014 - Accepted: September 15, 2014 - Distributed: August 31, 2015

(With 4 figures)

\begin{abstract}
Studies using chelonians as biosentinels of environment quality or health risks associated with turtle consumption are very rare, especially in the Amazon basin. This study aims to measure Mercury levels ( $\mathrm{Hg}$ ) in muscle, liver, fat and blood of Podocnemis unifilis from the lower Xingu River, assessing the possible difference in concentration between sexes and also evaluating the potential bioaccumulation along different body sizes. Samples were collected during the dry season (October 2012) and Mercury (Hg) concentrations were analysed by Cold Vapor Atomic Absorption Spectrometry (CVAAS). A total of 29 specimens of $P$. unifilis of different sizes showed low levels lower than $0.2 \mathrm{mg} / \mathrm{Kg}$ ). Higher $\mathrm{Hg}$ concentrations were found in the liver, and significant correlations between $\mathrm{Hg}$ concentrations in the different tissues were also detected. There was no difference between males and females and a negative correlation was found between $\mathrm{Hg}$ concentration and body size.
\end{abstract}

Keywords: heavy metal, turtles, Belo Monte, bioaccumulation.

\section{Concentrações de mercúrio em diferentes tecidos de Podocnemis unifilis (Podocnemididae: Testudines) do baixo Rio Xingu - Amazônia, Brasil}

\begin{abstract}
Resumo
Estudos utilizando quelônios como biosentinelas de qualidade ambiental ou de riscos à saúde associados ao consumo de tartarugas são raros, especialmente na bacia amazônica. Neste estudo foram medidos os níveis de mercúrio no músculo, fígado, gordura e sangue de Podocnemis unifilis do baixo Rio Xingu. Foram avaliadas as possíveis diferenças de concentração entre os sexos e também o potencial de bioacumulação ao longo de diferentes tamanhos corporais. A etapa de amostragem ocorreu durante o período seco (Outubro de 2012) e a quantificação de Mercúrio (Hg) foi realizada através de digestão ácida e análises por Espectrometria de Absorção Atômica com Vapor Frio (CVAAS). Um total de 29 amostras de Podocnemis unifilis, mesmo em diferentes tamanhos, mostraram concentrações de Hg menores que $0,2 \mathrm{mg} / \mathrm{kg}$. As concentrações mais elevadas de $\mathrm{Hg}$ foram encontradas no fígado, e também foram detectadas correlações significativas entre as concentrações de Hg nos tecidos. Não foram observadas diferenças significativas entre machos e fêmeas, sendo registrada correlação negativa entre a concentração de Hg e o tamanho do corpo.
\end{abstract}

Palavras-chave: metal pesado, quelônios, Belo Monte, bioacumulação.

\section{Introduction}

The Amazon basin is globally known for Mercury $(\mathrm{Hg})$ contamination found in its soils and rivers (Veiga et al., 1994; Barbosa et al., 1998; Maurice-Bourgoin et al., 2000), and in tissues of organisms, reaching high levels in predatory fish species due to biomagnification (Roulet et al., 2001; Belger and Forsberg, 2006; Kasper et al., 2009, 2012). A major proportion of studies on $\mathrm{Hg}$ contamination in the Amazon is focused on fish species from regions with

a historical presence of mining activities, installations of hydroelectric dams or in blackwater rivers with acid $\mathrm{pH}$ and others favourable conditions for $\mathrm{Hg}$ bioavailability (Santos et al., 2000; Dorea, 2003; Oliveira et al., 2010; Vieira et al., 2013).

On the other hand, studies using turtles as biosentinels of environmental quality or health risks associated with turtle consumption are very rare so far. However, turtles 
and reptiles in general have many advantages that make them good target species for ecotoxicology studies (Schneider et al., 2013). An example of these advantages is the long life of these animals, which can generate an idea of the state of contamination over time (Burger et al., 2006). They are also animals with a variable diet and thus so occupy different trophic levels (Burger et al., 2006). Furthermore, many indigenous and riverine communities along Amazon rivers use turtles as a major protein source (Vogt, 2001).

In the Xingu River basin, which is currently undergoing the process of construction of the Belo Monte hydroelectric plant and the installation of a large mining company, studies on mercury contamination have been conducted using fish species as biosentinels, given that fish are the main protein source for local populations. However, in this particular region consumption of turtles (especially tracajá - P. unifilis) is greatly appreciated, making them possible secondary sources of contamination. Moreover, in the Xingu basin, ecotoxicological studies with turtles are still quite scarce or even nonexistent.

For these reasons, this study aims to measure $\mathrm{Hg}$ level in muscle, liver, fat and blood of P. unifilis from low Xingu River, assessing the possible difference in concentration between sexes and also evaluating potential bioaccumulation in different body sizes of the turtle.

\section{Material and Methods}

The Xingu River basin is located on the right side of the Amazon river, covering more than 500,000 km² and occupying $24.5 \%$ of Pará state area. With a length of over $1600 \mathrm{~km}$ long, its major tributaries are the Iriri River upstream, and the Bacajá River downstream. The Xingu
River is classified as a clear water river, with low levels of dissolved nutrients and suspended matter. Waters are green in colour and transparency ranges from 1 to $4 \mathrm{~m}$ (Secchi disc), in the rainy and dry seasons respectively, with a mean $\mathrm{pH}$ of 5.5 and conductivity of $30 \mathrm{Uc} / \mathrm{cm}$ (Isaac, 2008).

Turtles were collected manually with the use of gillnets during the dry season (October 2012), in the lower Xingu river close to Senador José Porfírio municipality (Figure 1) This particular stretch of the Xingu River is known to support an abundant population of turtles during the spawning period, especially species such as the giant Amazon turtle (Podocnemis expansa) (Schweigger, 1812) and Tracajá (Podocnemis unifilis), the latter being the species targeted in this study.

The specimens captured were sexed visually by sexual dimorphism, and the curved carapace length (CCL), straight carapace length (SCL), plastron length (PL), plastron width (PW), head width (HW) and total weight (TW) were measured. Males have distinctive yellow spots on the head, and females have one diffuse spot, which later becomes brown.

Turtles were sacrificed and immediately after, blood was collected from their jugular veins with $5 \mathrm{~mL}$ syringes coated with EDTA. In a second step, the plastron was broken and from the exposed peritoneal region, using sterile scalpels and scissors, samples of liver, muscle and fat were collected, totalling four different tissues. All samples were kept in the refrigerator until laboratory analysis.

In the laboratory, tissue samples were cut or macerated into thin slices before weighing, to facilitate analysis. A total of $500 \mathrm{mg}$ of wet weight were transferred to $50 \mathrm{~mL}$ volumetric flasks, to which $1 \mathrm{~mL}$ of deionized water, $2 \mathrm{~mL}$ of $\mathrm{HNO}_{3}-\mathrm{HClO}_{4}(1+1)$, and $5 \mathrm{~mL}$ of $\mathrm{H}_{2} \mathrm{SO}_{4}$ were added.

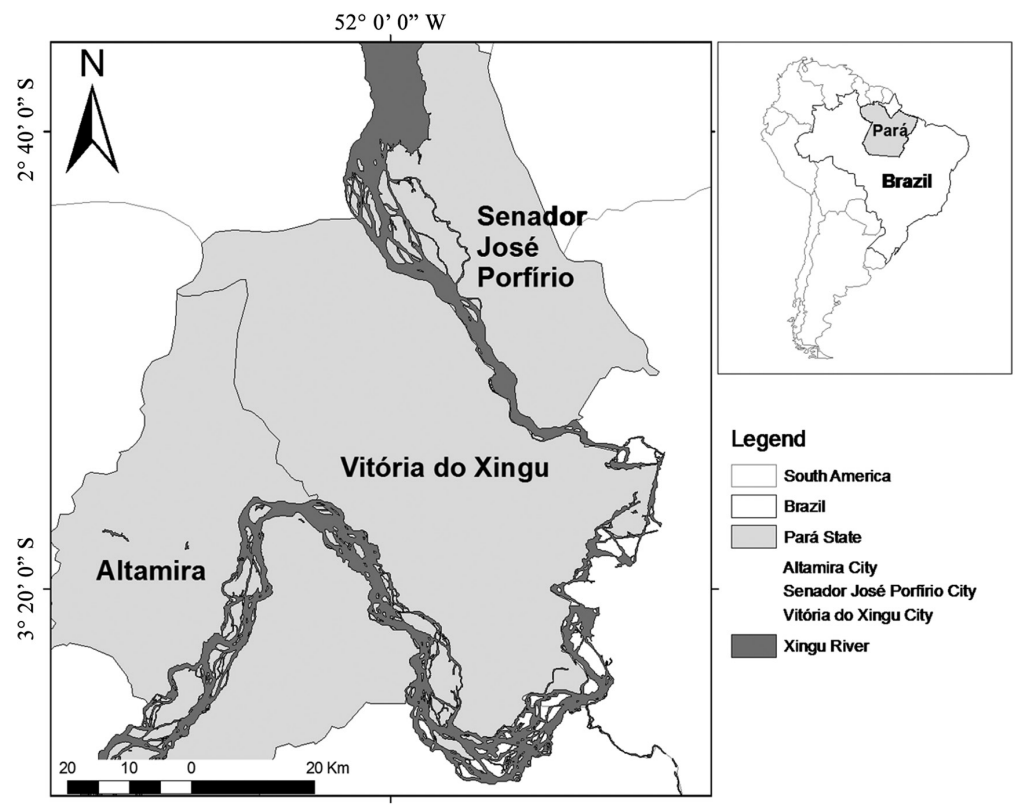

Figure 1. Map from the study area. Region near Senador José Porfírio municipality, Xingu River, Pará - Brazil. 
Samples were then heated on a hot plate to $200-230^{\circ} \mathrm{C}$ for 30 minutes. After cooling, the mixture was completed to $50 \mathrm{~mL}$ with deionized water, then $\mathrm{THg}$ was analysed using the method of Atomic Absorption Spectrometry by Cold Vapor (CVAAS) with the Mercury Analyzer, model HG-201, produced by SANSIO (Akagi et al., 1995). All analyses were performed in duplicate or triplicate, and were accompanied by quality control from certified reference material (CRM) Dorm -3 and Blood L -2 .

Differences in mercury concentrations between tissues, cohort length and sexes were tested using univariate PERMANOVA tests run on Euclidean distances matrices with 9999 permutations (Anderson, 2001). Calculations and tests were conducted using the PERMANOVA+ for PRIMER-E software program (Anderson et al., 2008).

\section{Results}

A total of 29 specimens of Podocnemis unifilis of different sizes were sampled. In all tissues analysed, none showed levels higher than $0.2 \mathrm{mg} / \mathrm{kg}$ (Table 1).

However, a notable different between concentrations in the tissues was detected (Pseudo $-\mathrm{F}=174.14$; $\mathrm{p}<0.001)$. In all samples analysed, the livers had higher $\mathrm{Hg}$ concentrations, decreasing in muscle and being almost equal for fat and blood (Figure 2). On average, liver tissue showed concentrations with $0.06 \mathrm{mg} / \mathrm{kg}$ of $\mathrm{Hg}$ higher than fat and blood $(\mathrm{p}<0.001)$ and $0.05 \mathrm{mg} / \mathrm{kg}$ of $\mathrm{Hg}$ than muscle $(p<0.001)$. A correlation between concentrations in the tissues was also observed (Table 2).

No difference in concentrations was found between sexes (Pseudo-F $=0.14977 ; p=0.8613$ ), despite livers from males presenting higher levels than those of females (Figure 3).

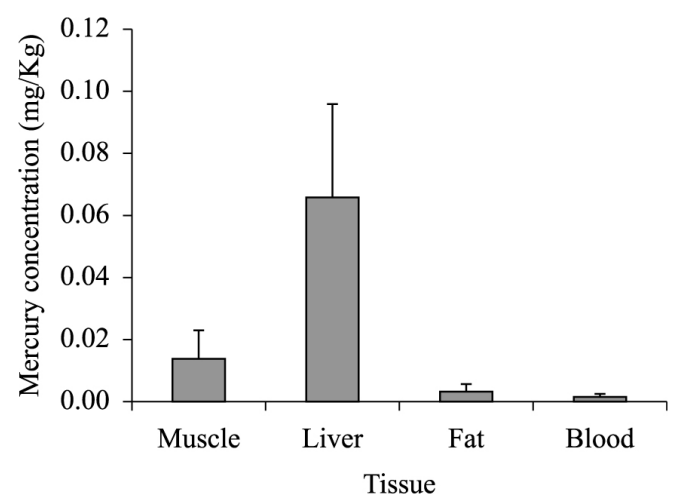

Figure 2. Mean and standard deviation of $\mathrm{Hg}$ concentration in the four tissues analysed from the 29 specimens of Podocnemis unifillis from lower Xingu River.

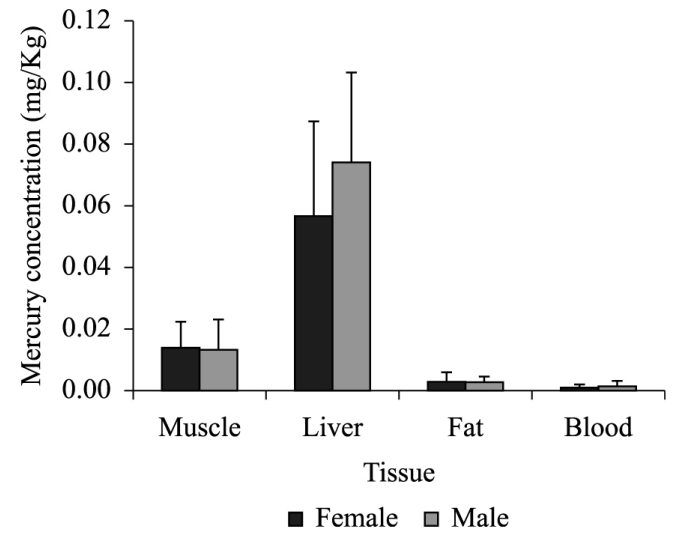

Figure 3. Mean and standard deviation of $\mathrm{Hg}$ concentration in the four tissues between females and males of Podocnemis unifilis. Lower Xingu River.

Table 1. Mean, standard deviation (SD), minimum and maximum of standard metrics measured from Podocnemis unifilis from the lower Xingu River. Where: CCL: Curved carapace length; SCL: Straight carapace length; PL: Plastron length; PW: Plastron width; CW: Carapace width; HW: Head width; TW: Total weight.

\begin{tabular}{ccc}
\hline Metrics & Mean \pm SD & Min - Max \\
\hline CCL $(\mathrm{mm})$ & $255.93 \pm 63.67$ & $167.0-418.0$ \\
SCL $(\mathrm{mm})$ & $235.37 \pm 61.89$ & $141.1-390.0$ \\
PL $(\mathrm{mm})$ & $207.60 \pm 56.81$ & $130.0-353.0$ \\
PW $(\mathrm{mm})$ & $176.93 \pm 44.68$ & $112.5-291.0$ \\
CW $(\mathrm{mm})$ & $87.32 \pm 20.73$ & $54.0-140.0$ \\
HW $(\mathrm{mm})$ & $34.71 \pm 7.78$ & $20.0-54.4$ \\
TW $(\mathrm{g})$ & $1770.51 \pm 1579.21$ & $420.0-6700.0$ \\
\hline
\end{tabular}

Table 2. Correlation $\left(\mathrm{R}^{2}\right.$ value) between the four tissues of Podocnemis unifilis analysed from the lower Xingu River.

\begin{tabular}{clll}
\hline & Muscle & Liver & Fat \\
\hline Muscle & & & \\
Liver & $0.6196^{* * *}$ & & \\
Fat & $0.3821^{* *}$ & $0.5087^{* * *}$ & \\
Blood & 0.1186 & 0.1003 & $0.1367^{*}$ \\
\hline
\end{tabular}

$* 0.01<\mathrm{p}<0.05 . * * 0.001<\mathrm{p}<0.01 . * * * \mathrm{p}<0.001$. 

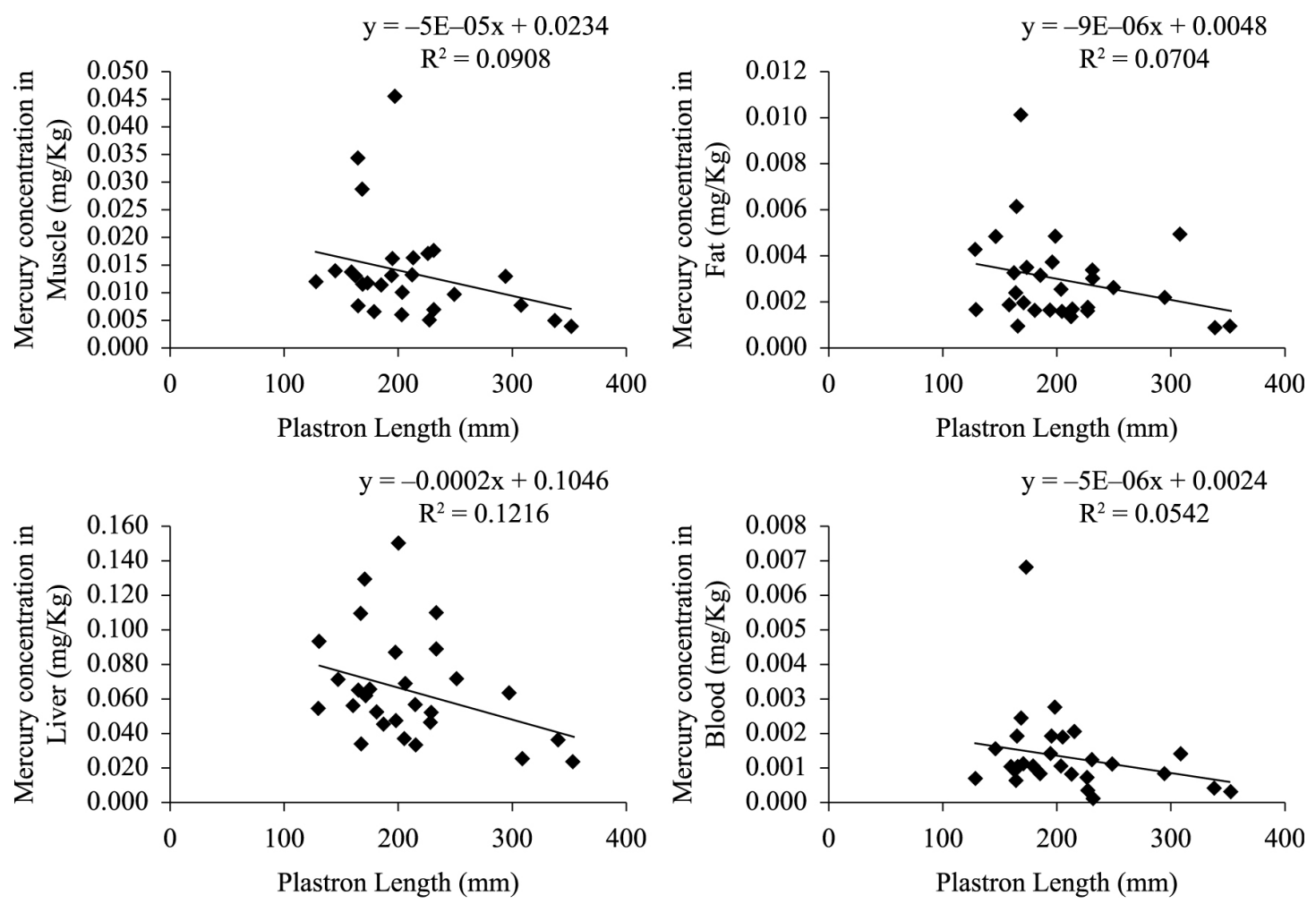

Figure 4. Correlation between Mercury concentration in the four tissues and plastron length in 29 individuals of Podocnemis unifilis from lower Xingu river.

A negative correlation was found between the $\mathrm{Hg}$ concentrations with body size, indicating that the $\mathrm{Hg}$ is not bioaccumulated in P. unifilis tissue during growth (Figure 4).

\section{Discussion}

The present study showed that $P$. unifilis from lower Xingu River is a species that accumulates very low levels of $\mathrm{Hg}$ throughout its life compared to other species of Amazon turtles. Results might reflect that $\mathrm{Hg}$ levels in P. unifilis are similar to levels found in herbivorous fish from other Amazonian basins (Lima et al., 2000; Barbosa et al., 2003). Similar $\mathrm{Hg}$ levels were found in P. unifilis from Negro River, a river with a natural occurrence of high $\mathrm{Hg}$ environmental contamination (Schneider et al., 2010). Thus, one can say that the lower Xingu River, like many other Amazon basin rivers, has occurrence of mercury in a bioavailable form for accumulation in organisms.

Most species of Testudines are classified as opportunistic omnivores (Legler, 1993). Recent studies have shown that P. unifilis as well as Podocnemis expansa are predominantly herbivorous; feeding mainly on plants. However, consumption of insects, crustaceans and mollusks also happens (Balensiefer and Vogt, 2006; Vogt, 2008). This fact supports the low levels of $\mathrm{Hg}$ found in all tissues. Despite this, Golet and Haines (2001) suggest that chelonians can eliminate $\mathrm{Hg}$ from tissues at higher rates than fish. Thus, equilibrium between ingested rate and elimination rates of mercury can exist.

As for tissues, higher levels found in liver than other tissues are expected for almost all organisms, which have their major detoxification processes located in this organ (Newman, 2010). The positive relation between tissues allows an estimate, by collecting a single tissue, of the levels of mercury in remaining tissues.

The lack of difference in concentrations of $\mathrm{Hg}$ between males and females can be explained by the fact that there is no difference in trophic levels between sexes for this species (Lara et al., 2012). Some studies indicate a difference in feeding preference between males and females. Females would feed more fruits and seeds and males more stalks and shoots (Teran et al., 1995). However, research with stable isotopes applied to assess the trophic relationship of $P$. unifilis and P. expansa showed no differences in isotopic signatures between both sexes. Despite different sizes and different sources, males and females are in the same trophic level (Lara et al., 2012).

Finally, a negative correlation between $\mathrm{Hg}$ concentration and size, as in the result of this study, has been reported in similar studies with other Podocnemis species such as Podocnemis erythrocephala (Spix, 1824) and Podocnemis sextuberculata (Boulenger, 1889) (Schneider et al., $2009,2010)$. The idea of changes in diet during growth as observed in Vogt and Benitez (1993) and Vogt (2008) 
could explain this result. In another example observed in a study with Trachemys scripta (Schoepff, 1792) and Chelonia mydas (Linnaeus, 1958), adults were herbivorous, and opportunistic carnivores while juveniles were more carnivorous (Clark and Gibbons, 1969; Bezerra et al., 2012, 2013). Additionally, another hypothesis is that smaller individuals could obtain some Mercury from their eggs, such as has been observed for Chelydra serpentina (Linnaeus, 1758) (Ashpole et al., 2004) and also Trachemys scripta (Burger and Gibbons, 1998).

The carapace and nails, keratinized tissues not analysed here, could be excellent indicators of $\mathrm{Hg}$ exposure over time (Bezerra et al., 2013). More extensive studies on $\mathrm{Hg}$ contamination using turtles as bioindicators, with different approaches such as physiology, histopathology and analysis of biomarkers should be carried out in the Amazon region, first for a better understanding of phenomena observed in studies such as this one, and second, because in the Amazon basin, especially in the Xingu River region, this kind of approach is extremely scarce.

\section{Acknowledgements}

This study was carried out during the course of aquatic reptiles ecology offered by Post Graduate Programme in Aquatic Ecology and Fisheries (UFPA). Fieldwork was accomplished with the aid of IBAMA at the Tabuleiro do Embaubal Research Station. We thank Dr. Juarez Pezzuti and Dra. Daniely Félix Silva for collecting the samples, and the biology students Carine Morais and Gabriela Mardok for help during processing of tissues. We thank the Evandro Chagas Institute, for providing support for chemical analysis. Tommaso Giarrizzo receives a productivity grant from CNPq (process: $308278 / 2012-7$ ) and PNPD/CAPES grant.

\section{References}

AKAGI, H., MALM, O., KINJO, Y., HARADA, M., BRANCHES, FJP., PFEIFFER, WC. and KATO, H., 1995. Methylmercury pollution in the Amazon, Brazil. The Science of the Total Environment, vol. 175, no. 2, p. 85-95. http://dx.doi.org/10.1016/0048-9697(95)04905-3.

ANDERSON, MJ., 2001. Permutation tests for univariate or multivariate analysis of variance and regression. Canadian Journal of Fisheries and Aquatic Sciences, vol. 58, no. 3, p. 626-639. http://dx.doi.org/10.1139/f01-004.

ANDERSON, MJ., GORLEY, RN. and CLARKE, KR., 2008. PERMANOVA for PRIMER: guide to software and statistical methods. Plymouth: PRIMER-E.

ASHPOLE, SL., BISHOP, CA. and BROOKS, RJ., 2004. Contaminant residues in snapping turtle (Chelydra s. serpentina) eggs from the Great Lakes-St. Lawrence River Basis (1999 to 2000). Archives of Environmental Contamination and Toxicology, vol. 47, no. 2, p. 240-252. http://dx.doi.org/10.1007/s00244-0043012-6. PMid:15386150.

BALENSIEFER, DC. and VOGT, RC., 2006. Diet of Podocnemis unifilis (Testudines, Podocnemididae) during the dry season in the Mamirauá Sustainable Development Reserve, Amazonas,
Brazil. Chelonian Conservation and Biology, vol. 5, no. 2, p. 312-317. http://dx.doi.org/10.2744/1071-8443(2006)5[312:DO PUTP]2.0.CO;2.

BARBOSA, AC., SILVA, SR. and DÓREA, JG., 1998. Concentration of mercury in hair of indigenous mothers and infants from the Amazon basin. Archives of Environmental Contamination and Toxicology, vol. 34, no. 1, p. 100-105. http://dx.doi.org/10.1007/ s002449900291. PMid:9419279.

BARBOSA, AC., SOUZA, J., DÓREA, JG., JARDIM, WF. and FADINI, PS., 2003. Mercury biomagnification in a tropical black water, Rio Negro, Brazil. Archives of Environmental Contamination and Toxicology, vol. 45, no. 2, p. 235-246. http://dx.doi.org/10.1007/ s00244-003-0207-1. PMid:14565582.

BELGER, L. and FORSBERG, BR., 2006. Factors controlling $\mathrm{Hg}$ levels in two predatory fish species in the Negro river basin, Brazilian Amazon. The Science of the Total Environment, vol. 367, no. 1, p. 451-459. http://dx.doi.org/10.1016/j.scitotenv.2006.03.033. PMid:16690103.

BEZERRA, MF., LACERDA, LD., COSTA, BG. and LIMA, EH., 2012. Mercury in sea turtles, Chelonia mydas (Linnaeus, 1958), from the coast of Ceará, NE Brazil. Anais da Academia Brasileira de Ciencias, vol. 84, no. 1, p. 123-128. http://dx.doi. org/10.1590/S0001-37652012005000002. PMid:22441601.

BEZERRA, MF., LACERDA, LD., LIMA, EH. and MELO, MT., 2013. Monitoring mercury in green sea turtles using keratinized carapace fragments (scutes). Marine Pollution Bulletin, vol. 77, no. 1-2, p. 424-427. http://dx.doi.org/10.1016/j.marpolbul.2013.09.020. PMid:24095202.

BURGER JUNIOR, L., MCKENZIE, D., THACKSTON, R. and DEMASO, SJ., 2006. The role of farm policy in achieving large-scale conservation: Bobwhite and buffers. Wildlife Society Bulletin, vol. 34, no. 4, p. 986-993. http://dx.doi.org/10.2193/00917648(2006)34[986:TROFPI]2.0.CO;2.

BURGER, J. and GIBBONS, JW., 1998. Trace elements in egg contents and egg shells of slider turtles (Trachemys scripta) from the Savannah River Site. Archives of Environmental Contamination and Toxicology, vol. 34, no. 4, p. 382-386. http://dx.doi.org/10.1007/ s002449900334. PMid:9543509.

CLARK, DB. and GIBBONS, JW., 1969. Dietary shift in the turtle Pseudemys scripta (Schoepff) from youth to maturity. Copeia, vol. 4, p. 704-706.

DOREA, JG., 2003. Fish are central in the diet of Amazonian riparians: should we worry about their mercury concentrations? Environmental Research, vol. 92, no. 3, p. 232-244. http://dx.doi. org/10.1016/S0013-9351(02)00092-0. PMid:12804520.

GOLET, WJ. and HAINES, TA., 2001. Snapping turtles (Chelydra serpentina) as monitors for Mercury contamination of aquatic environments. Environmental Monitoring and Assessment, vol. 71, no. 3, p. 211-220. http://dx.doi.org/10.1023/A:1011802117198. PMid:11683228.

ISAAC, VJ., 2008. Diagnóstico ambiental da AHE - Belo Monte e Baixo Rio Xingu - Ictiofauna e Pesca. Brasília: Norte Energia.

KASPER, D., PALERMO, EFA., BRANCO, CWC. and MALM, O., 2012. Evidence of elevated mercury levels in carnivorous and omnivorous fishes downstream from an Amazon reservoir. Hydrobiologia, vol. 694, no. 1, p. 87-98. http://dx.doi.org/10.1007/ s10750-012-1133-x.

KASPER, D., PALERMO, EFA., DIAS, ACMI., FERREIRA, GL., LEITAO, RP., BRANCO, CWC. and MALM, O., 2009. Mercury 
distribution in different tissues and trophic levels of fish from a tropical reservoir, Brazil. Neotropical Ichthyology, vol. 7, no. 4, p. 751-758. http://dx.doi.org/10.1590/S1679-62252009000400025.

LARA, NRF., MARQUES, TS., MONTELO, KM., ATAÍDES, ÁG., DE VERDADE, LM. and MALVÁSIO, A., 2012. A trophic study of the sympatric Amazonian freshwater turtles Podocnemis unifilis and Podocnemis expansa (Testudines, Podocnemidae) using carbon and nitrogen stable isotope analyses. Canadian Journal of Zoology, vol. 90, no. 12, p. 1394-1401. http://dx.doi. org/10.1139/cjz-2012-0143.

LEGLER, JM., 1993. Morphology and physiology of the Chelonia. In GLASBY, CJ., ROSS, GJB. and BEESLEY, PL. (Eds.). Fauna of Austrália. Canberra: Australian Government Publishing Servic. vol. 2, p. 108-119.

LIMA, APS., MULLER, RCS., SARKIS, JES., ALVES, CN., BRABO, E. and SANTOS, E., 2000. Mercury contamination in fish from Santarém, Pará state, Brazil. Environmental Research, vol. 83, no. 2, p. 117-122. http://dx.doi.org/10.1006/enrs.2000.4051. PMid:10856184.

MAURICE-BOURGOIN, L., QUIROGA, I., CHINCHEROS, J. and COURAU, P., 2000. Mercury distribution in waters and fishes of the upper Madeira rivers and mercury exposure in riparian Amazonian populations. The Science of the Total Environment, vol. 260 , no. 1-3, p. 73-86. http://dx.doi.org/10.1016/S00489697(00)00542-8. PMid:11032117.

NEWMAN, MC., 2010. Fundamentals of ecotoxicology. 3rd ed. Boca Raton, FL: Taylor \& Francis/CRC Press.

OLIVEIRA, RC., DOREA, JG., BERNARDI, JVE., BASTOS, WR., ALMEIDA, R. and MANZATTO, AG., 2010. Fish consumption by traditional subsistence villagers of the Rio Madeira (Amazon): Impact on hair mercury. Annals of Human Biology, vol. 37, no. 5, p. 629-642. http://dx.doi.org/10.3109/03014460903525177. PMid:20132080.

ROULET, M., GUIMARÃES, J-RD. and LUCOTTE, M., 2001. Methylmercury production and accumulation in sediments and soils of an amazonian floodplain - Effect of seasonal inundation. Water, Air, and Soil Pollution, vol. 128, no. 1/2, p. 41-60. http:// dx.doi.org/10.1023/A:1010379103335.

SANTOS, ECD., JESUS, IM., BRABO, ES., LOUREIRO, ECB., MASCARENHAS, AFDS., WEIRICH, J., CAMARA, VM. and CLEARY, D., 2000. Mercury exposures in riverside Amazon communities in Para, Brazil. Environmental Research, vol. 84, no. 2, p. 100-107. http://dx.doi.org/10.1006/enrs.2000.4088. PMid:11068923.

SCHNEIDER, L., BELGER, L., BURGER, J. and VOGT, R., 2009. Mercury bioacumulation in four tissues of Podocnemis erythrocephala (Podocnemididae: Testudines) as a function of water parameters. The Science of the Total Environment, vol. 407, no. 3, p. 1048-1054. http://dx.doi.org/10.1016/j.scitotenv.2008.09.049. PMid:19022475.

SCHNEIDER, L., BELGER, L., BURGER, J., VOGT, RC. and FERRARA, CR., 2010. Mercury Levels in Muscle of Six Species of Turtles Eaten by People Along the Rio Negro of the Amazon Basin. Archives of Environmental Contamination and Toxicology, vol. 58, no. 2, p. 444-450. http://dx.doi.org/10.1007/ s00244-009-9358-z. PMid:19621205.

SCHNEIDER, L., MAHER, W., GREEN, A. and VOGT, RC., 2013. Mercury contamination in reptiles: an emerging problem with consequences for wild life and human health. In KIM, KH. and BROWN, RJC. Mercury: sources, applications and health impacts. 1st ed. New York: Nova Science Publishers. p. 173-232.

TERAN, AF., VOGT, RC. and GOMEZ, MFS., 1995. Food habits of an assemblage of five species of turtles in the Rio Guaporé, Rondônia, Brazil. Journal of Herpetology, vol. 29, no. 4, p. 536547. http://dx.doi.org/10.2307/1564736.

VEIGA, MM., MEECH, JA. and ONATE, N., 1994. Mercury Pollution from Deforestation. Nature, vol. 368, no. 6474, p. 816-817. http://dx.doi.org/10.1038/368816a0. PMid:8159239.

VIEIRA, SM., ALMEIDA, R., HOLANDA, IBB., MUSSY, MH., GALVAO, RCF., CRISPIN, PTB., DOREA, JG. and BASTOS, WR., 2013. Total and methyl-mercury in hair and milk of mothers living in the city of Porto Velho and in villages along the Rio Madeira, Amazon, Brazil. International Journal of Hygiene and Environmental Health, vol. 216, no. 6, p. 682-689. PMid:23340120.

VOGT, RC. and BENITEZ, JLV., 1993. Species abundance and biomass distributions in freshwater turtles. In Proceedings ot the Conservation, Restoration and Management of Tortoises and Turtles: an International Conference, 1993. Purchase. Purchase, NY: State University of New York. 494 p.

VOGT, RC., 2001. Turtles of the Rio Negro. In CHAO, NL., PETRY, P., PRANG, G., SONNESCHIEN, L. and TLUSTY, M. Conservation and management of ornamental fish resources of the Rio Negro Basin, Amazonia, Brazil. Manaus: Editora Universidade do Amazonas. p. 245-262.

VOGT, RC., 2008. Amazon turtles. Lima: Gráfica Bíblos. 